\title{
Acute soft head syndrome in a sickle cell disease patient
}

\author{
Catherina Zadeh ${ }^{1}$, Vanessa Rameh ${ }^{1}$, Lamya Ann Atweh ${ }^{1 *}$ \\ 1. Department of Radiology, American University of Beirut hospital, Beirut, Lebanon \\ * Correspondence: Lamya Ann Atweh, American University of Beirut Medical Center, PO BOX: 11-0236, Riad El Solh, Beirut 1107 \\ 2020, Beirut, Lebanon \\ (入la17@aub.edu.lb)
}

Radiology Case. 2021 Apr; 15(4):1-6 :: $\quad$ DOI: 10.3941/jrcr.v15i4.4026

\begin{abstract}
Acute soft head syndrome is an extremely rare complication in children with sickle cell anemia. We present a 16-year old male patient known to have sickle cell anemia who presented to our emergency department with low grade fever, headache, skull pain and swelling. Magnetic Resonance of the brain was done demonstrating subgaleal collections overlying calvarial signal abnormalities. The combination of clinical and radiological findings were indicative of acute soft head syndrome. Acute soft head syndrome is a rare complication in children with sickle cell anemia and the pathophysiology is related to osteonecrosis and bone infarcts of the calvarium as well as secondary reactive sub-galeal collections. Treatment includes conservative management with intravenous fluids and analgesics, in addition, our patient was treated with antibiotics since differentiation clinically and by imaging can be challenging. Acute soft head syndrome should be considered in the differential diagnosis of headache and skull swelling in children with sickle cell anemia.
\end{abstract}

\section{CASE REPORT}

\section{CASE REPORT}

We present a 16-year old male patient known sickle cell anemia (HB-SS) at age of 6 months who presented to our emergency department with few hours onset of low-grade fever and headache. The headache was intractable and all over his head. He described it as pulsating and non-tolerable and could not be alleviated by analgesic. The patient did not report any history of head trauma. The patient was hemodynamically stable. On physical exam, the neurologic examination was unremarkable with normal motor power, sensations and reflexes. The medical team noticed a tender scalp swelling that was mostly located over the left hemisphere and right occipital region.
On investigation, laboratory studies showed: elevated white count (20400/mm, reference range: 4000-11000/mm), CRP (79.7mg/l, reference range: $0.0-2.5 \mathrm{mg} / \mathrm{L}), \mathrm{LDH}$ (851IU/L reference range: 44.97 , total Bilirubin $(7 \mathrm{mg} / \mathrm{dl}$ reference range:0.0-1.2 $\mathrm{mg} / \mathrm{dl})$ and reticulocyte count $(3.6$, reference range: $4-6.5 \mathrm{mil} / \mathrm{cu} . \mathrm{mm})$. The hemoglobin and hematocrit levels were low $(9.4 \mathrm{~g} / \mathrm{dl}$ reference range: $12-18$ $\mathrm{g} / \mathrm{dl}$ and $27 \%$ reference range: $37-54 \%$ respectively). His chest radiograph showed no acute cardiopulmonary process.

Two days after admission, non-enhanced MRI of the brain was performed and showed diffuse subgaleal collections with a predominant high T2 signal, iso to low T1 signal along with areas of high FLAIR and restricted diffusion signal in the frontal, bilateral parietal and occipital calvarium and small foci of susceptibility on $\mathrm{T} 2 *$ suggestive of punctate blood 
products (Figure 1). The largest collection in the right occipital region measured $1.5 \mathrm{~cm}$ in maximum thickness. The underlying calvarium demonstrated high signal on FLAIR signal within the bone with areas of high signal on diffusion images in the regions of bone infarcts (Figure 1). No associated epidural hematomas or extra-axial collections. No cortical breaks or erosions were noted.

There are many differential diagnoses for headache and skull swelling in patients with sickle cell disease. In the setting of trauma, extra-axial hematomas would be the first consideration. With the lack of trauma history, differential diagnosis includes osteonecrosis, osteomyelitis with overlying abscesses/collections and finally "'acute soft head syndrome', which is a diagnosis of exclusion.

The patient was admitted and started on intravenous fluid, broad spectrum antibiotics, analgesics and oxygen. The patient continued to improve clinically with significant improvement in his headache and resolution of his skull swellings, decrease in fever and normalization of his white count. Osteomyelitis was felt to be an unlikely possibility, however, could not be completely excluded and the patient was discharged on antibiotics including levofloxacin and clindamycin.

\section{DISCUSSION}

Sickle cell disease (SCD) is one of the most common hemoglobinopathies worldwide with a high incidence noted in African, afro-american, afro-Caribbean, Middle East and Indian descent [1]. The incidence of sickle cell disease is estimated globally between 300,000 and 400,000 neonates each year, the majority in sub-Saharan Africa [2]. The disease is caused by a mutation in the beta globin gene which results in an abnormally shaped red blood cell. The sickled, readily polymerized hemoglobin causes obstruction of the microcirculation. Patients with sickle cell disease suffer from diverse neurological manifestations.

\section{Etiology \& Demographics:}

Acute soft head syndrome is an extremely rare complication in SCD and only few cases are reported in the literature $[3,4]$ and the pathogenesis of this condition is not fully understood yet [3,5]. The most reasonable discussed mechanism is the fact that sickled RBC induces osteonecrosis and bone infarcts of the calvarium as well as cortical disruption and secondary reactive subgaleal collections [3]. Only nine cases reported associated epidural bleed that were attributed to the same pathophysiology described above but was not present in our case [5]. On the other hand, Berger et al concluded that unilateral skull swelling associated with fever and pain increases the possibility of osteomyelitis in sickle cell disease patients [6]. Although our patient had bilateral collections, he however also had fever and positive blood cultures for Granulicatella adiacens; and therefore, osteomyelitis could not be ruled out with certainty. Echocardiography performed to rule out endocarditis was negative.

\section{Clinical \& Imaging findings:}

We present a case of acute soft head syndrome and the MR imaging findings in a patient with SCD who presented to the Emergency Department with severe headache, skull swelling and fever. This diagnosis of acute soft head syndrome in patients with sickle cell disease is a rare and challenging complication to diagnose [3]. Patients usually presents with headache and scalp swelling. It is a diagnosis of exclusion and needs to be differentiated from other common causes of headache in this population.

The cornerstone of diagnosis is imaging with MRI being the most sensitive modality for diagnosis [7]. CT has a limited sensitivity compared to MRI to detect these bone infarcts and is only able to demonstrate swelling and fluid [3]. Bone scan has a high sensitivity in detecting regions of osteonecrosis with photopenia surrounded by a rim of increased uptake, however, bone scans lacks the anatomic detail to delineate the extent of the abnormality and is also limited in assessing the associated soft tissue abnormalities [4]. MRI imaging features include high signal on $\mathrm{T} 2$ and FLAIR images, iso to low signal on $\mathrm{T} 1$, and high signal on diffusion within the calvarium. Within the soft tissues, there is extensive high FLAIR and T2 signal with possible associated foci of diffusion restriction in addition to susceptibility foci on $\mathrm{T} 2 *$ representing blood products. In addition to establishing a diagnosis, MRI is also important in these patients to evaluate for associated intracranial abnormalities such as intracranial extra-axial collections or bleed, which our patient did not have. It is also important to evaluate for other manifestations of sickle cell disease such as infarcts, silent ischemia, hemorrhage, and posterior reversible encephalopathy.

\section{Treatment \& Prognosis:}

The management of this condition is usually conservative with IV hydration and analgesics and patients report significant improvement after few days. Commonly, as in our patient, treatment will also include broad spectrum antibiotics since differentiation clinically and by imaging can be challenging. Our patient was treated appropriately, and he was discharged home without complications. Follow up MRI one year later showed complete resolution of the extra-axial collections with persistent heterogeneous intramedullary high FLAIR signal sequelae of prior bone infarct (Figure 2).

\section{Differential Diagnosis:}

Acute soft head syndrome is a diagnosis of exclusion. It must be differentiated from osteomyelitis which needs to be treated aggressively with antibiotics in addition to the IV hydration and analgesic. Osteomyelitis show cortical destruction and periosteal reaction on computed tomography images. Post contrast MRI images show rim enhancement of the associated abscesses. Other differential diagnoses include epidural and subdural hematomas that can cause scalp swelling secondary to acute trauma. Associate fractures will tilt toward this diagnosis in the appropriate clinical context. 


\section{TEACHING POINT}

The case presented illustrates a rare and benign complication seen in patients with sickle cell disease. The pathophysiology of acute soft head syndrome is related to osteonecrosis and bone infarcts of the calvarium as well as secondary reactive sub-galeal collections. The mainstay of treatment is conservative management of the vaso-occlusive crises with intravenous fluids and analgesics. Acute soft head syndrome should be considered in the differential diagnosis of headache and skull swelling in children with sickle cell anemia.

\section{REFERENCES}

1. Thust SC, Burke C, Siddiqui A. Neuroimaging findings in sickle cell disease. The British journal of radiology 2014;87(1040):20130699. PMID:24847772

2. Kato GJ, Piel FB, Reid CD, Gaston MH, Ohene-Frempong K, Krishnamurti L, Smith WR, Panepinto JA, Weatherall DJ, Costa FF, Vichinsky EP. Sickle cell disease. Nature Reviews Disease Primers. 2018 Mar 15;4(1):1-22.

3. Akodu SO, Njokanma OF, Diaku-Akinwumi IN, Ubuane PO, Adediji UO. Acute soft head syndrome in children with sickle cell anaemia in lagos, Nigeria. Indian journal of hematology \& blood transfusion: an official journal of Indian Society of Hematology and Blood Transfusion 2014;30(Suppl 1):67-9. PMID:25332539

4. Alli NA, Wainwright RD, Mackinnon D, Poyiadjis S, Naidu G. Skull bone infarctive crisis and deep vein thrombosis in homozygous sickle cell disease- case report and review of the literature. Hematology (Amsterdam, Netherlands) 2007;12(2):169-74. PMID:17454200

5. Arends S, Coebergh JA, Kerkhoffs JL, van Gils A, Koppen H. Severe unilateral headache caused by skull bone infarction with epidural haematoma in a patient with sickle cell disease. Cephalalgia: an international journal of headache 2011;31(12):1325-8. PMID:21803935

6. Berger E, Saunders N, Wang L, Friedman JN. Sickle cell disease in children: differentiating osteomyelitis from vasoocclusive crisis. Archives of pediatrics \& adolescent medicine 2009;163(3):251-5. PMID:19255393

7. Saito N, Nadgir RN, Flower EN, Sakai O. Clinical and radiologic manifestations of sickle cell disease in the head and neck. Radiographics: a review publication of the Radiological Society of North America, Inc 2010;30(4):1021-34. PMID:20631366 


\section{FIGURES}

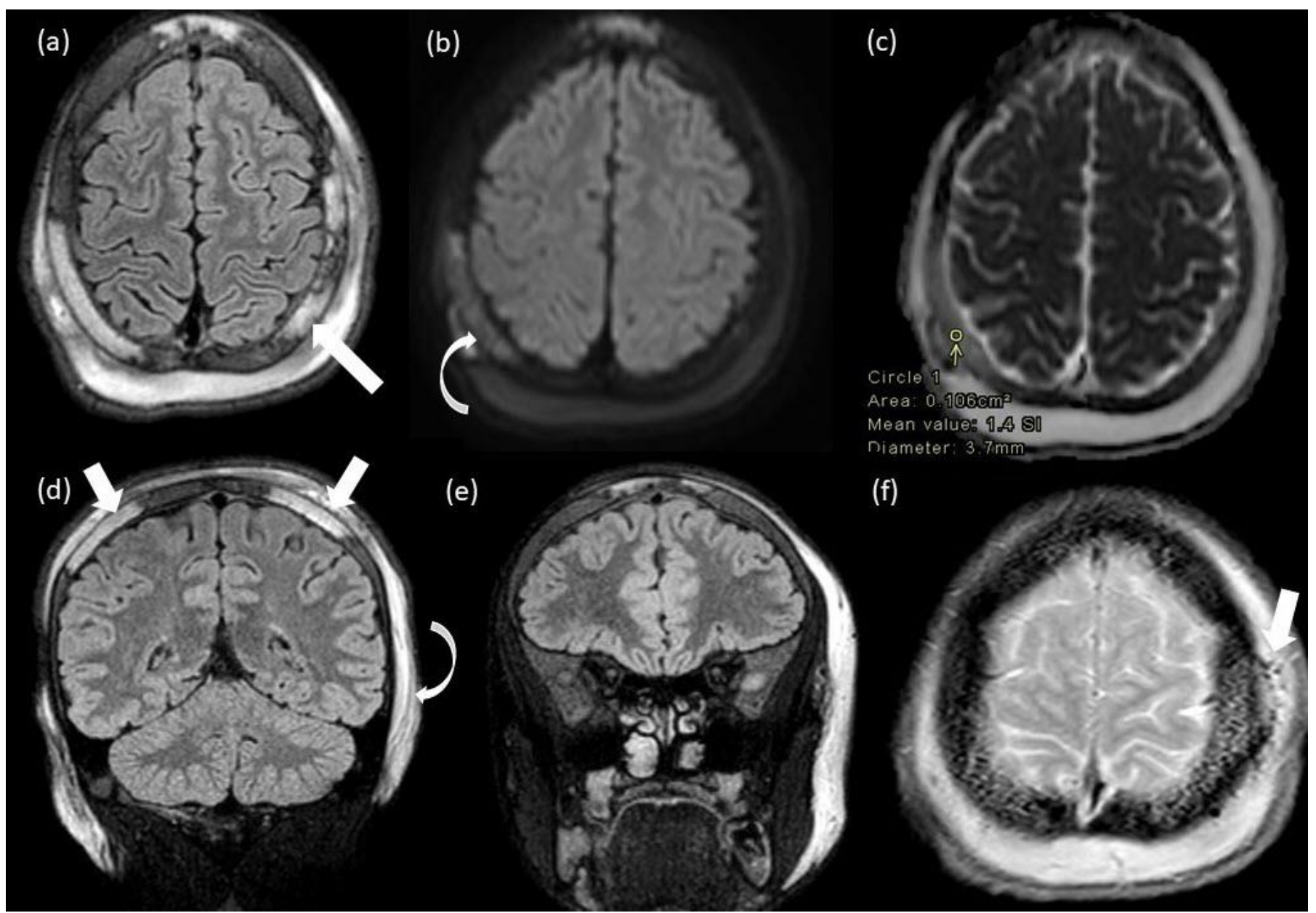

Figure 1: 16-year-old male patient with sickle cell disease and acute soft head syndrome.

Findings: (a) Axial FLAIR image near the level of the vertex showing bilateral high signal in the calvarium (white arrow). (b) Corresponding axial diffusion weighted image, (c) reconstructed ADC map showing high signal intensity within the calvarium (curved arrow) ( $\mathrm{d}$ and e) Coronal FLAIR MRI showing extensive bilateral parietal hyper-intense signal in the calvarium (white arrow) suggestive of bone infarcts with associated extensive subgaleal collections and edema extending to the face and cheek (curved arrows). (f) Axial T2* images demonstrate punctate susceptibility foci within the subgaleal collections suggestive of associated blood products.

Technique: Non-enhanced study performed on 1.5 Tesla magnet (a) Axial FLAIR, 2mm slice thickness, TE:347.702, TR: 4800. (b) Axial diffusion with reconstructed ADC map, $5 \mathrm{~mm}$ slice thickness, TE: 105.406, TR: 3302. (c) and (d) Coronal FLAIR, 2mm slice thickness, TE:347.702, TR: 4800. (e) Axial T2*, 4 mm slice thickness, TE: 18.42, TR: 826.72. 


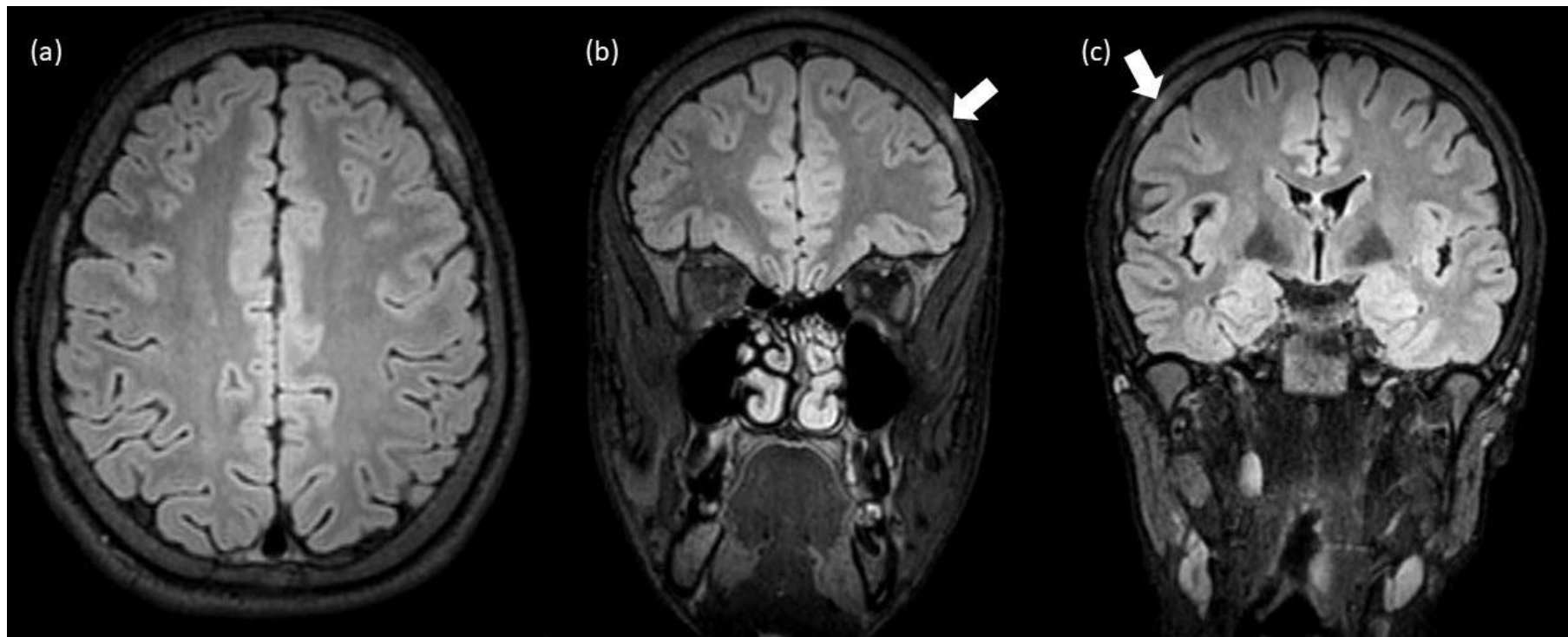

Figure 2: 16-year-old male patient with sickle cell disease and acute soft head syndrome. Follow up MRI one year after first MRI was performed.

Findings: (a) Axial FLAIR image near the level of the vertex showing resolution of the bilateral subgaleal collections. (b) and (c) Coronal FLAIR MRI showing resolution of the bilateral extra-axial collections with persistent heterogeneous intramedullary high FLAIR signal (arrows) corresponding to the areas of previous infarcts.

Technique: Non-enhanced study performed on 3 Tesla magnet (a) Axial FLAIR, 2mm slice thickness, TE:319.59, TR: 4800. (b) and (c) Coronal FLAIR 2mm slice thickness, TE:319.59, TR:4800.

\begin{tabular}{|l|l|}
\hline Etiology & $\begin{array}{l}\text { Osteonecrosis and bone infarcts as well as cortical disruption and secondary reactive subgaleal } \\
\text { collections. }\end{array}$ \\
\hline Incidence & Very rare, to our knowledge 6 cases were described in the literature. \\
\hline Gender Ratio & None \\
\hline Age predilection & None \\
\hline Risk Factors & Sickle cell disease \\
\hline Treatment & IV hydration and analgesics. \\
\hline Prognosis & Good prognosis with significant improvement post treatment. \\
\hline Findings on imaging & $\begin{array}{l}\text { CT scan: swelling and fluid collections. } \\
\text { Bone scan: photopenia surrounded by a rim of increased uptake. } \\
\text { MR: high signal on T2 and FLAIR images, iso to low signal on T1, and high signal on diffusion } \\
\text { within the calvarium. }\end{array}$ \\
\hline
\end{tabular}

Table 1: Summary table of acute soft head syndrome. 


\begin{tabular}{|c|c|c|c|}
\hline & Acute soft head syndrome & Osteomyelitis & $\begin{array}{l}\text { Subdural and epidural } \\
\text { hematomas in the setting of } \\
\text { trauma. }\end{array}$ \\
\hline X-Ray & - & $\begin{array}{l}\text { A central area of radiolucency with a } \\
\text { surrounding thick rim of reactive bone } \\
\text { sclerosis. }\end{array}$ & Fracture lines. \\
\hline $\mathbf{U S}$ & $\begin{array}{l}\text { Soft tissue edema is seen as } \\
\text { areas of hypervascularity. }\end{array}$ & $\begin{array}{l}\text { Limited use since it cannot assess bones. } \\
\text { It can be useful for detecting soft tissue or } \\
\text { subperiosteal collections which are seen as } \\
\text { periosteal elevation with an underlying } \\
\text { fluid collection. }\end{array}$ & $\begin{array}{l}\text { Soft tissue edema is seen as } \\
\text { areas of hypervascularity } \\
\text { around the affected bone on } \\
\text { color Doppler. }\end{array}$ \\
\hline CT & $\begin{array}{l}\text { Assessment of soft tissue } \\
\text { swelling and fluid } \\
\text { collections. }\end{array}$ & $\begin{array}{l}\text { Shows osseous changes such as: } \\
\text { 1. cortical destruction. periosteal } \\
\text { reactions. } \\
\text { 2. sequestrum formation. } \\
\text { Poor soft tissue resolution. }\end{array}$ & $\begin{array}{l}\text { Bone fractures. } \\
\text { Assessment of soft tissue } \\
\text { swelling and fluid collections. }\end{array}$ \\
\hline MRI & 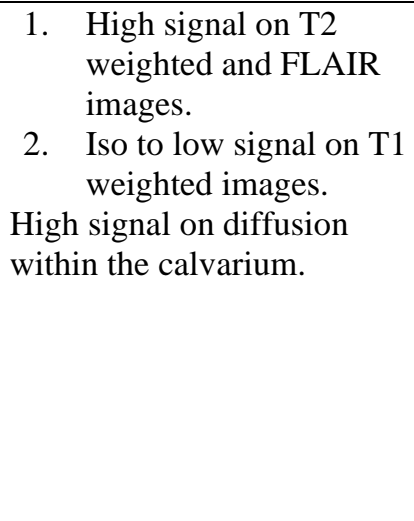 & $\begin{array}{l}\text { Bone marrow edema: } \\
\text { 1. low signal on T1W images. } \\
\text { 2. high signal on fluid-sensitive and } \\
\text { post-contrast sequences } \\
\text { Intraosseous and subperiosteal abscesses: } \\
\text { 1. low signal on T1W images. } \\
\text { 2. high signal on fluid-sensitive } \\
\text { sequences. } \\
\text { 3. peripheral enhancement on post } \\
\text { contrast images. } \\
\text { Sinus tract is seen as a linear fluid-filled } \\
\text { structure extending from bone to the skin } \\
\text { surface. }\end{array}$ & $\begin{array}{l}\text { In the setting of trauma MRI is } \\
\text { used to assess intraparenchymal } \\
\text { contusions. }\end{array}$ \\
\hline $\begin{array}{l}\text { Pattern of } \\
\text { contrast } \\
\text { enhancement }\end{array}$ & $\begin{array}{l}\text { No enhancement in the } \\
\text { absence of superimposed } \\
\text { infection. }\end{array}$ & $\begin{array}{l}\text { 1. Peripherally enhancing intraosseous } \\
\text { lesion. } \\
\text { 2. Non-enhancing sequestrum. } \\
\text { 3. Sinus tract. }\end{array}$ & None \\
\hline Scintigraphy & $\begin{array}{l}\text { Osteonecrosis on bone scan } \\
\text { shows photopenia } \\
\text { surrounded by a rim of } \\
\text { increased uptake. }\end{array}$ & $\begin{array}{l}\text { In a triple-phase bone scan, technetium- } \\
\text { 99m-labelled MDP shows high tracer } \\
\text { uptake in all three phases. }\end{array}$ & - \\
\hline FDG-PET & - & $\begin{array}{l}\text { Hypermetabolic activity in the affected } \\
\text { tissues. Has the highest sensitivity in } \\
\text { chronic osteomyelitis. }\end{array}$ & - \\
\hline
\end{tabular}

Table 2: Differential diagnosis table for acute soft head syndrome.

\section{ABBREVIATIONS}

$\mathrm{CRP}=\mathrm{C}$ reactive protein

$\mathrm{CT}=$ Computed tomography

FLAIR = Fluid-attenuated inversion recovery

$\mathrm{Hb}-\mathrm{SS}=$ Sickle cell anemia

LDH = Lactic Acid Dehydrogenase

MR = Magnetic Resonance

MRI = Magnetic Resonance Imaging

$\mathrm{RBC}=$ Red Blood Cells

$\mathrm{SCD}=$ Sickle cell disease

\section{KEYWORDS}

Acute soft head syndrome; sickle cell disease; osteonecrosis; osteomyelitis; headache

\section{Online access}

This publication is online available at: www.radiologycases.com/index.php/radiologycases/article/view/4026

\section{Peer discussion}

Discuss this manuscript in our protected discussion forum at: www.radiolopolis.com/forums/JRCR

\section{Interactivity}

This publication is available as an interactive article with scroll, window/level, magnify and more features. Available online at www.RadiologyCases.com
Published by EduRad

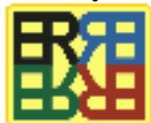

www.EduRad.org 